Article

\title{
New Combined Depressant/Collectors System for the Separation of Powellite from Dolomite and the Interaction Mechanism
}

\author{
Yunlou Qian ${ }^{1,2, *}$, Wei Ding ${ }^{2}$, Zhen Wang ${ }^{2, * \mathbb{D}}$ and Yang Peng ${ }^{2}$ \\ 1 Intelligent Safe Collaborative Innovation Center, Zhejiang College of Security Technology, \\ Wenzhou 325016, China \\ 2 Key Laboratory of Solid Waste Treatment and Resource Recycle Ministry of Education, \\ Southwest University of Science and Technology, Mianyang 621010, China; \\ dingwei@mails.swust.edu.cn (W.D.); pengyang@mails.swust.edu.cn (Y.P.) \\ * Correspondence: qianyunlou@sina.com (Y.Q.); wangzhen@swust.edu.cn (Z.W.)
}

Received: 28 February 2020; Accepted: 20 March 2020; Published: 24 March 2020

\begin{abstract}
The flotation beneficiation of powellite from dolomite was achieved with a new reagent system that consists of a mixed collector of sodium oleate $(\mathrm{NaOl})$ and benzohydroxamic acid (BHA) and a depressant sodium hexametaphosphate (SHMP). The interaction mechanism of the reagent regime with minerals was studied using zeta potential and X-ray photoelectron spectroscopy (XPS) detection together with crystal chemistry and interaction energy analysis. The matching features of $\mathrm{O}-\mathrm{O}$ distance in BHA with that in saline minerals and active site density/activity were used as methods to explain the reagent/mineral interaction. The results of microflotation finally established the new reagent regime at $\mathrm{pH}$ 8-12: $2.5 \times 10^{-4} \mathrm{M}$ SHMP, $2 \times 10^{-4} \mathrm{M}$ mixed collector containing $1.5 \times$ $10^{-4} \mathrm{M} \mathrm{NaOl}$ and $0.5 \times 10^{-4} \mathrm{M}$ BHA. SHMP selectively depresses the adsorption of $\mathrm{NaOl}$ and $\mathrm{BHA}$ onto dolomite but minimally affects the adsorption of $\mathrm{NaOl}$ and $\mathrm{BHA}$ on the powellite surface.
\end{abstract}

Keywords: powellite; selectivity; mixed collector; crystal chemistry; Ca-bearing mineral; flotation

\section{Introduction}

Powellite $\left[\mathrm{CaMoO}_{4}\right]$, an important oxide molybdenum mineral that serves as an alternative source to supply the increasingly depleted molybdenum $\left[\mathrm{MoS}_{2}\right]$ resource, is often concentrated by flotation. It mainly occurs in scheelite or molybdenite deposits; for example, $60 \%$ of Mo is distributed in powellite in Yangjiazhangzi molybdenum deposits in China [1]. It often coexists with calcite and dolomite in $\mathrm{Ca} / \mathrm{Mg}$-bearing minerals. The active sites on the powellite and dolomite surface where the oleate collector can absorb on are commonly $\mathrm{Ca} / \mathrm{Mg}$ atoms [2,3]. As exposed $\mathrm{Ca} / \mathrm{Mg}$ atoms, i.e., possible active sites exist on the surfaces of both minerals, the flotation selectivity is poor when oleate was used as a collector. In the flotation of scheelite and fluorite, two additional Ca-containing minerals, some cationic amines, and collector mixture have been employed to strengthen the flotation selectivity from Ca-bearing gangue minerals [4].

On the other hand, some highly selective chelate collectors, particularly hydroxamate types, have also been used for the efficient flotation of Ca-bearing mineral systems in the last decade [5-8]. These include (sodium) benzohydroxamate, salicylhydroxamic acid [9], amide hydroxamate [10], and alkyl hydroxamate [11]. The reaction mechanism of benzohydroxamic acid (BHA) with scheelite was investigated through a variety of detection methods, including zeta potential, Fourier transform infrared spectroscopy, and X-ray photoelectron spectroscopy, and the most accepted hypothesis is that a five-membered ring chelate was formed after BHA adsorption with the $\mathrm{Ca}$ atom on the scheelite surface [12]. Amide hydroxamate (AH) was first introduced as a collector for Ca minerals flotation by 
Deng et al [10]. They found that AH exhibits superior appetency to scheelite against calcite, which is in favor of their selective separation. The mechanism was ascribed to the unique bond patterns and double hydrophobic groups of the $\mathrm{AH}$ reagent, and the selective formation of intermolecular hydrogen bonds on scheelite rather than the calcite surface. Almost all above studies referring to the interaction between a hydroxamate type collector with Ca-bearing minerals show that the $-\mathrm{CONHOH}$ group (oximido) of the collector reveals strong chelation with Ca atoms on the mineral's exposed surface. However, few reports have focused on hydroxamate as a collector for powellite flotation.

Recently, researchers made an attempt to use selective BHA collector for separating fluorite from calcite without any depressant, and the zeta potential and XPS detection results reveal much easier chemisorption of BHA on fluorite than calcite [13]. The larger Ca density and increased Ca activity on the fluorite surface compared with calcite surface and stronger hydrogen bonding with BHA and a weaker electrostatic repulsion with $\mathrm{BHA}^{-}$for fluorite surface are thought to be responsible for the selective flotation of fluorite from calcite based on the important role of mineral crystal chemistry in flotation. Gao et al. [14] found that octyl hydroxamic acid chemisorbed on the scheelite surface by chelation of the collectors' oxygen and Ca atoms on the mineral surface. The two investigations directly provide new ideas on the flotation of powellite from dolomite using oleate. In this study, BHA was considered a cocollector of sodium oleate $(\mathrm{NaOl})$ to improve its selectivity for the powellite/dolomite system under the assistance of the depressant SHMP. The interaction mechanism was investigated by a variety of detection means and deeply analyzed using a suggested comparative adsorption model.

\section{Experimental}

\subsection{Reagents and Minerals}

BHA with a purity of $98 \%$, analytically pure sodium oleate $(\mathrm{NaOl})$, and sodium hexametaphosphate (SHMP) were all obtained from Sinopharm Chemical Reagent Co., Ltd. The chemical structures of the reagents are shown in Figure 1, which was drawn and optimized using Material Studio 5.0. The $\mathrm{pH}$ was controlled with sodium hydroxide and muriatic acid stock solutions. The water used in all the tests was deionized water $(18.2 \mathrm{M} \Omega \cdot \mathrm{cm})$.

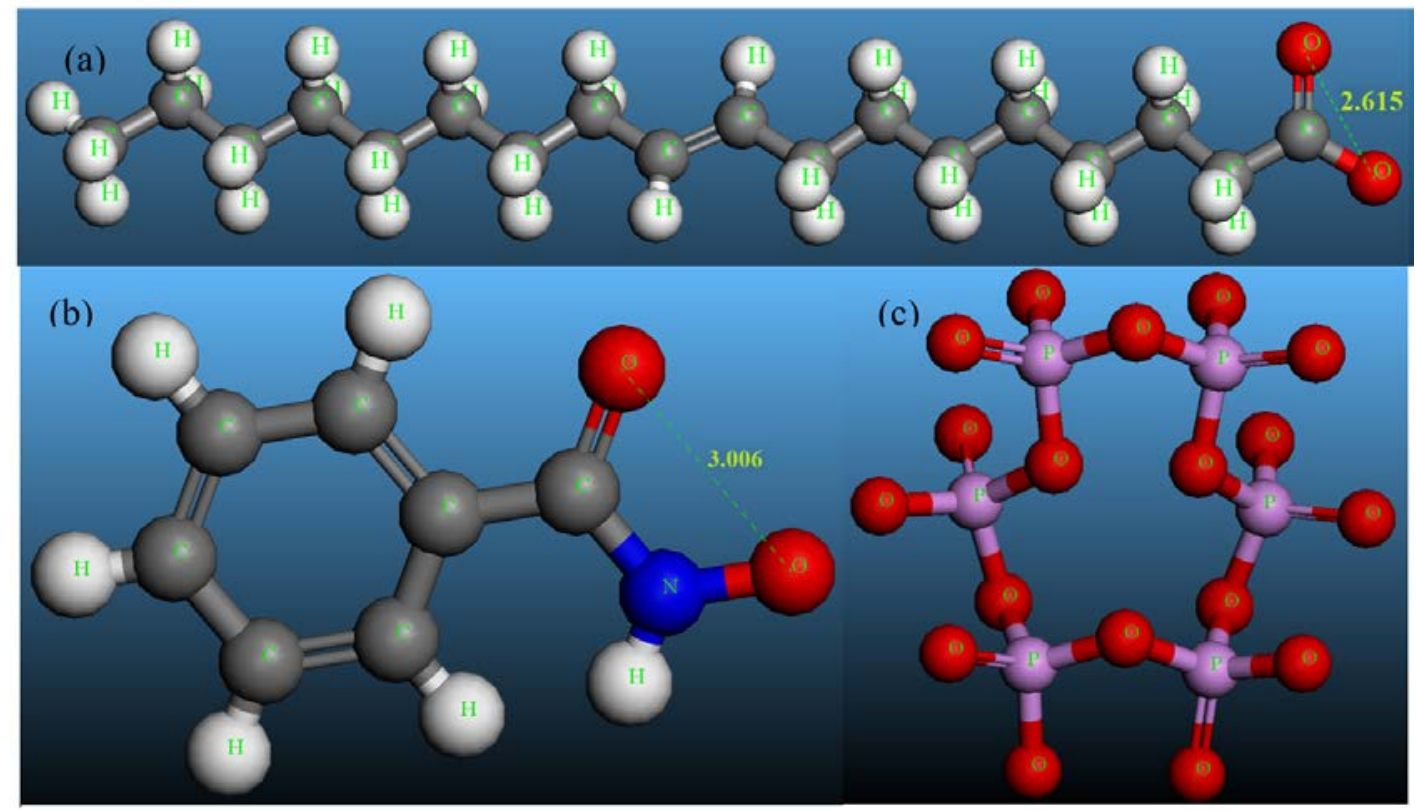

Figure 1. Molecule structures of $\mathrm{Ol}^{-}(\mathbf{a})$, benzohydroxamic acid (BHA) (b), and $\left(\mathrm{PO}_{3}\right)_{6}^{6-}$ (c) (white, $\mathrm{H}$; gray, C; red, O; pink, P; blue, N). 
Pure crystals of powellite and calcite were obtained from Guangxi Zhuang Autonomous Region and purchased from Beijing Mineral Specimens Limited Liability Company, respectively. From the X-ray diffraction spectrum (Figure 2), the distribution of diffraction peaks is highly consistent with the corresponding standard spectrum obtained from Jade 6.0 software. The contents of $\mathrm{CaO}+\mathrm{MgO}$ and Mo in dolomite and powellite (Table 1) also approximate the theoretical grade of them in corresponding minerals, respectively. The purity of all minerals was greater than $98 \%$ obtained by X-ray diffraction spectra and chemical analysis results. The chemical analysis was conducted using atomic absorption spectrometer. The main exposed surface for dolomite and powellite are (104) [15] and (112) [16] cleavage plane, respectively. The minerals were dried and ground in a ceramic ball mill to avoid any ferrous contaminants. Then, both powders were screened to $-74+38 \mu \mathrm{m}$ using the sieves with 74 and $38 \mu \mathrm{m}$ apertures. About $-2 \mu \mathrm{m}$ minerals were further ground in agate mortar from the $-38 \mu \mathrm{m}$ fractions. The $-74+38 \mu \mathrm{m}$ and $-2 \mu \mathrm{m}$ fractions were used for microflotation/XPS tests and other characterization measurements, respectively.

Table 1. Chemical analysis results of dolomite and powellite used in the experiments.

\begin{tabular}{cccccccc}
\hline \multirow{2}{*}{ Mineral } & $\mathbf{7}$ Elements Content (wt. \%) \\
\cline { 2 - 8 } & $\mathbf{M o}$ & $\mathbf{C a O}$ & $\mathbf{M g O}$ & $\mathbf{S i O}_{\mathbf{2}}$ & $\mathbf{W O}_{3}$ & $\mathbf{F e}_{\mathbf{2}} \mathbf{O}_{3}$ & $\mathbf{A l}_{\mathbf{2}} \mathbf{O}_{\mathbf{3}}$ \\
\hline Dolomite & - & 30.01 & 21.22 & 2.16 & - & 0.39 & 0.22 \\
Powellite & 47.04 & 27.34 & - & 1.18 & 0.09 & 0.27 & 0.24 \\
\hline & $\mathrm{P}_{2} \mathrm{O}_{5}$ & $\mathrm{MnO}$ & $\mathrm{ZnO}$ & $\mathrm{SO}_{3}$ & $\mathrm{BaO}$ & $\mathrm{TiO}_{2}$ & $\mathrm{SrO}$ \\
Dolomite & 4.47 & 4.59 & 0.94 & 1.24 & 0.68 & - & 0.16 \\
Powellite & 3.68 & 2.77 & 0.049 & 0.68 & 2.28 & 1.08 & 1.25 \\
\hline
\end{tabular}
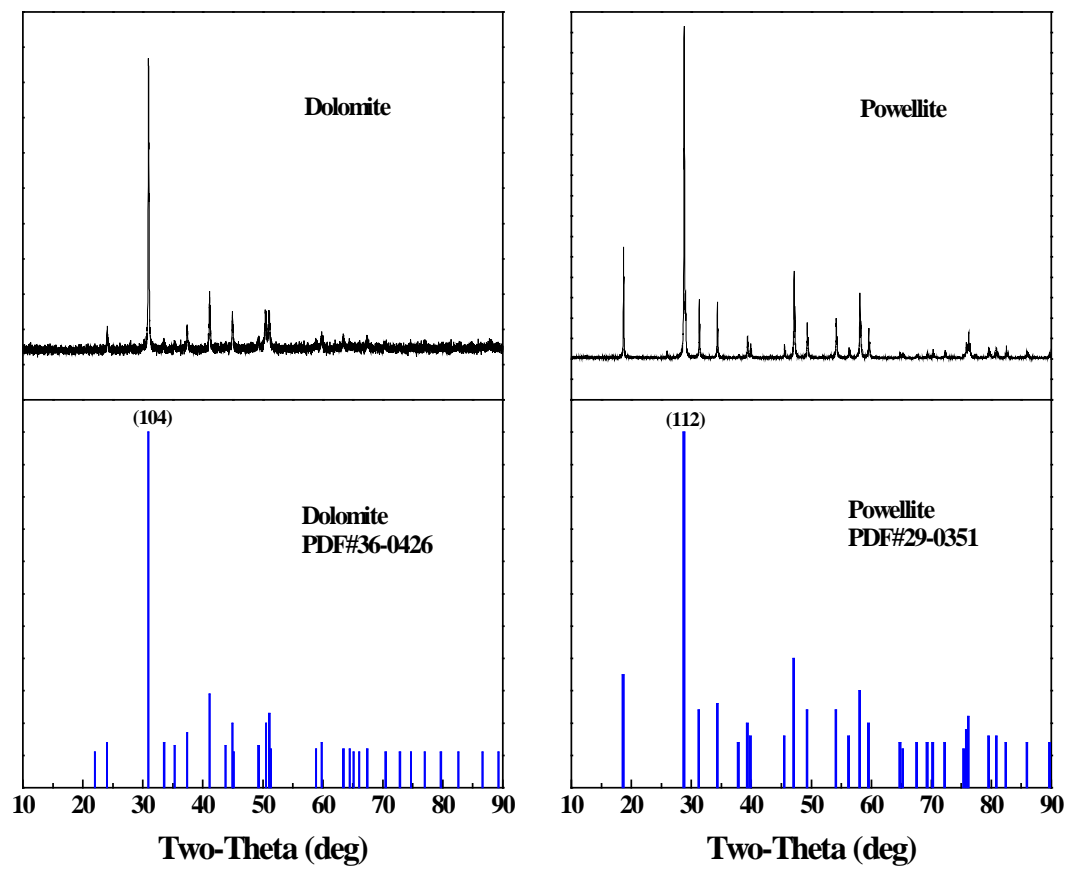

Figure 2. Experimentally obtained XRD patterns of dolomite and powellite and corresponding powder diffraction file (PDF) data.

\subsection{Flotation Tests}

Microflotation tests were conducted in a mechanically agitated flotation machine (XFG, $40 \mathrm{~mL}$, Jilin Exploration Machinery Plant, Jilin, China) at about $25^{\circ} \mathrm{C}$ room temperature, and the impeller speed was maintained at $1800 \mathrm{rpm}$ for each flotation operation. A mineral sample (2.0 g) was placed in the cell with $35 \mathrm{~mL}$ of DI water. After $2 \mathrm{~min}$ of agitation, the pulp was conditioned for an additional $2 \mathrm{~min}$ 
while the desired $\mathrm{pH}$ value was measured using a $\mathrm{pH}$ meter (PHS-3C). Then, the depressant, collector(s) and frother $(20 \mu \mathrm{L} / \mathrm{L}$ terpineol) were added successively; the conditioning times for the depressant, collector(s) and frother are 2, 3, and $2 \mathrm{~min}$, respectively. After $3.5 \mathrm{~min}$ of flotation, both floated and nonfloated fractions were dried in an oven at $40{ }^{\circ} \mathrm{C}$ and then weighed to calculate flotation recovery. Previous papers have reported similar flow with the same flotation machine [17-19]. It should be noted that the flotation tests with the different minerals were made separately.

Three flotation tests were performed under the same conditions, and the average values were reported. Note that for collector mixture, $\mathrm{BHA}$ and $\mathrm{NaOl}$ were premixed pro rata.

\subsection{Zeta Potential Measurements}

The zeta potential of minerals before and after treatment with reagent(s) were measured using a Coulter DELSA 440S II electrokinetic instrument. A powder sample $(2.0 \mathrm{mg})$ was first ground to $\sim 2 \mu \mathrm{m}$ in an agate mortar and then transferred to a $100 \mathrm{~mL}$ beaker containing $50 \mathrm{~mL}$ of $1 \times 10^{-3} \mathrm{~mol} / \mathrm{L}$ $\mathrm{KCl}$ (Note that with different background electrolytes, the potential value may have subtle difference but the tendency is the same) $[20,21]$ as a supporting solution at a given $\mathrm{pH}$ and reagent concentration. After being magnetically stirred for $10 \mathrm{~min}$ followed by settling for $7 \mathrm{~min}$, the supernatant liquor was used for zeta potential measurements. Repeated tests revealed a measurement error of $\pm 2 \mathrm{mV}$. The environmental temperature was maintained at $25.0 \pm 0.5^{\circ} \mathrm{C}$.

\subsection{XPS Detection}

The XPS spectra for powellite and dolomite particles with and without treatment by SHMP, NaOl, or HXMA-8 at the same concentration used in flotation were recorded with a K-Alpha 1063 (Thermo Scientific Co., USA) spectrometer, which employs $\mathrm{Al} \mathrm{K} \alpha$ as sputtering source at $12 \mathrm{kV}$ and $6 \mathrm{~mA}$ with $1.0 \times 10^{-9}$ Pa pressure in the analytical chamber. The $C 1$ s peak served as a reference to binding energy (BE) for uncharged hydrocarbon at $284.8 \mathrm{eV}$, and binding energies in all other spectra for that sample corrected for this shift [22-24]. The quantification and curve fitting of the spectra were determined using Thermo Scientific Avantage software.

\subsection{Molecular Dynamics Simulation}

Dolomite (104) and powellite (112) surfaces were generated from a crystal cell by virtue of the Building Surface module in Material Studio 5.0 (Accelry Corporation, Washington, DC, USA). The molecule structure of collectors and the depressant was optimized using the $\mathrm{DMol}^{3}$ module. The distance between two $\mathrm{O}$ atoms in $\mathrm{BHA}, \mathrm{NaOl}$ molecule and $\mathrm{CO}_{3}^{2-}$ of dolomite, and $\mathrm{MoO}_{4}^{2-}$ of powellite was measured using the distance tool, and the $\mathrm{Ca}-\mathrm{O}$ bond in dolomite and powellite was also obtained by the same method.

The simulation and calculation were performed in the experiential and parameterized universal force field in the Forcite module. The interaction energies between the collector(s) and minerals were characterized by the $\Delta E$ value. A more negative $\Delta E$ value indicates stronger adsorption between the reagent and mineral surfaces [25-27]. The Material Studio 5.0 package was used to perform the simulations and calculations. It should be noted that for single $\mathrm{NaOl}$, BHA, or SHMP interactions with the mineral surface, two corresponding anions were introduced, while one BHA anion together with one $\mathrm{NaOl}$ anion were placed onto the mineral surface for the $\mathrm{BHA} / \mathrm{NaOl}$ collector mixture.

\section{Results and Discussion}

\subsection{Microflotation}

Figure 3 shows the influence of the collector concentration on both minerals' recoveries using single $\mathrm{NaOl}$ or BHA as collectors with and without $1.5 \times 10^{-4} \mathrm{M}$ depressant SHMP at $\mathrm{pH}$ 8.5. Without SHMP, the recoveries of both minerals moderately increase as the $\mathrm{NaOl}$ concentration in pulp increases. When the concentration of $\mathrm{NaOl}$ is greater than $15 \times 10^{-5} \mathrm{M}(80.59 \%$ and $71.63 \%$ recoveries for dolomite 
and powellite, respectively), the recoveries cannot be obviously improved, as shown in Figure 3a. At this dosage, dolomite recovery is approximately $9 \%$ higher than powellite. The lack of a further increase in the recovery at high $\mathrm{NaOl}$ concentrations is commonly ascribed to the near-saturated monolayer adsorption of the collector [28]. While in the presence of SHMP, dolomite recovery is reduced compared with powellite, reflecting a stronger depression of SHMP on dolomite compared with powellite $[29,30]$. $\mathrm{NaOl}$ displays almost no selectivity for the flotation of powellite from dolomite even with the depressant SHMP. In contrast, the BHA collector, which is selective in other minerals systems, was employed to separate powellite/dolomite. The results are illustrated in Figure $3 \mathrm{~b}$. Mineral recoveries with different reagent schemes reach the maximum of $51.98 \%$ for powellite/BHA, $55.27 \%$ for powellite/SHMP/BHA, 36.99\% for dolomite/BHA, and 30.06\% for dolomite/SHMP/BHA at a BHA concentration of $5 \times 10^{-5} \mathrm{M}$. For the mineral/collector system, it is generally assumed that the saturated monolayer absorption of the collector causes the highest mineral recovery, and the further increase in collector concentration mineral recovery will steadily decrease as a response to the gradually increased hydrophilic surface due to the reversely orientated molecular structure on the mineral surface with its hydrophilic head group towards the solution [14,29]. Powellite recovery is 15-20\% higher than dolomite, and the difference in mineral recoveries would increase as SHMP was introduced, illustrating a stronger depression of SHMP on dolomite compared with that on powellite using BHA as collector. BHA shows some selectivity for powellite/dolomite separation even without SHMP, but its collecting power is weaker than $\mathrm{NaOl}$.

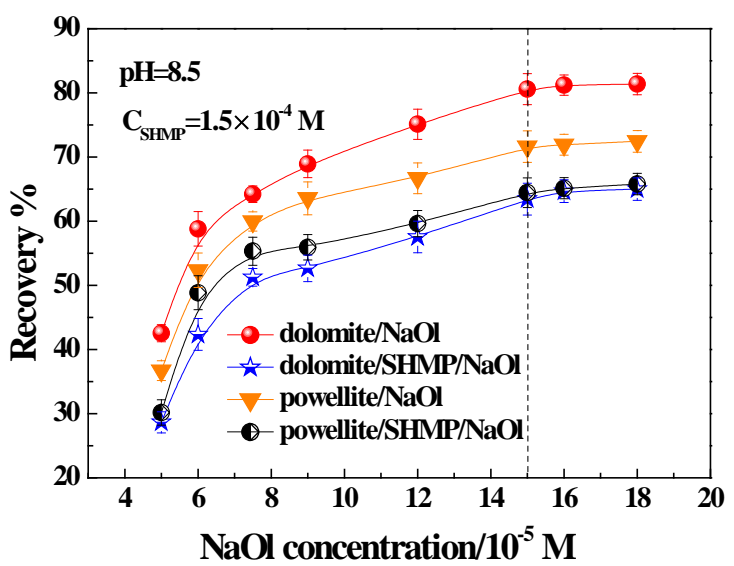

(a)

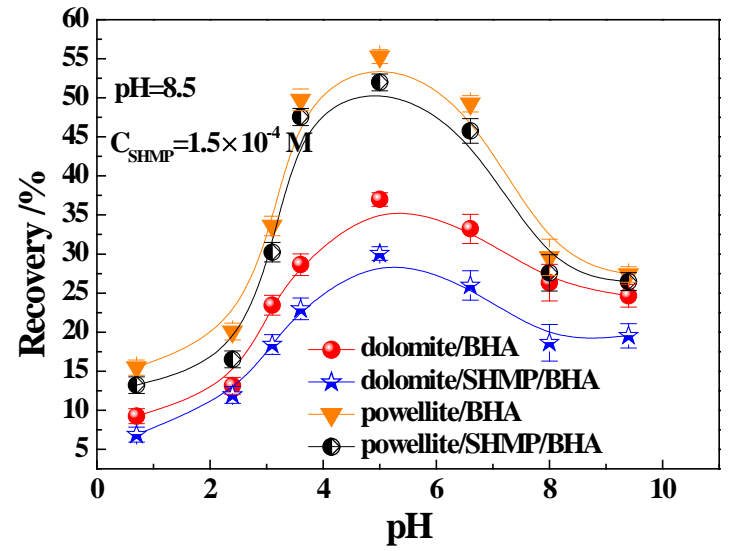

(b)

Figure 3. Effects of (a) $\mathrm{NaOl}$ and (b) BHA dosages on the flotation of minerals with and without sodium hexametaphosphate (SHMP).

The synergistic effect between collectors can make their mixture have both stronger collecting power and selectivity compared with each collector alone [30,31]. Thus, based on the results above, the $\mathrm{BHA} / \mathrm{NaOl}$ mixture was used as a collector to identify a new reagent regime for the efficient separation of powellite from dolomite. With a fixed total concentration of $20 \times 10^{-5} \mathrm{M}$, the effect of the molar ratio of $\mathrm{NaOl} / \mathrm{BHA}$ on the recovery was investigated through flotation tests at $\mathrm{pH} 8.5$, and the results are shown in Figure $4 \mathrm{a}$. The optimal selectivity for the powellite/dolomite system with a mixed collector was obtained with a constant molar ratio of 3 for $\mathrm{C}_{\mathrm{NaOl}} / \mathrm{C}_{\mathrm{BHA}}$, especially using SHMP as the depressant. Under this condition, powellite exhibits the highest recovery of approximately $84 \%$. When the $\mathrm{NaOl}$ ratio is low, the difference in recovery of two minerals is also large; however, given the increased cost of a BHA collector compared with fatty acid collector, this ratio is not economical. With a constant molar ratio of 3 for $\mathrm{C}_{\mathrm{NaOl}} / \mathrm{C}_{\mathrm{BHA}}$, the mineral recovery versus the collector mixture concentration in the absence and presence of SHMP was studied. The results are presented in Figure $4 \mathrm{~b}$. The recoveries of both minerals increase with the increasing $C_{\operatorname{mix}}$ until its value reached $20 \times 10^{-5}$ 
$\mathrm{M}\left(5 \times 10^{-5} \mathrm{M}\right.$ BHA and $\left.15 \times 10^{-5} \mathrm{M} \mathrm{NaOl}\right)$, and maximum recoveries of $86.78 \%$ were obtained for dolomite with $(\mathrm{NaOl})_{3}(\mathrm{BHA}), 84.37 \%$ for powellite with $(\mathrm{NaOl})_{3}(\mathrm{BHA}), 83.59 \%$ for powellite with $\mathrm{SHMP} /(\mathrm{NaOl})_{3}(\mathrm{BHA})$, and $71.24 \%$ for dolomite with $\mathrm{SHMP} /(\mathrm{NaOl})_{3}(\mathrm{BHA})$.

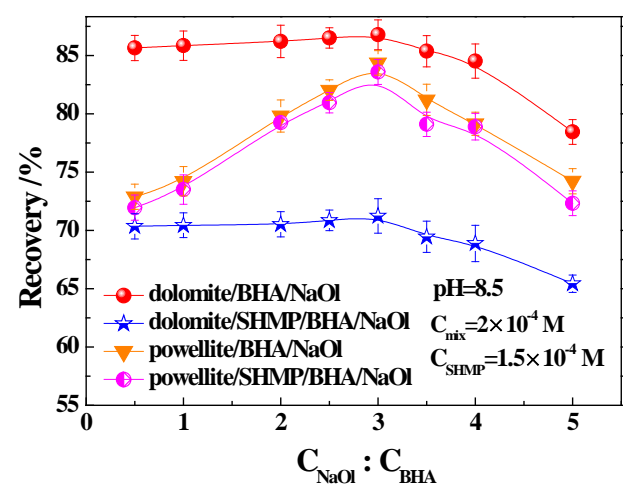

(a)

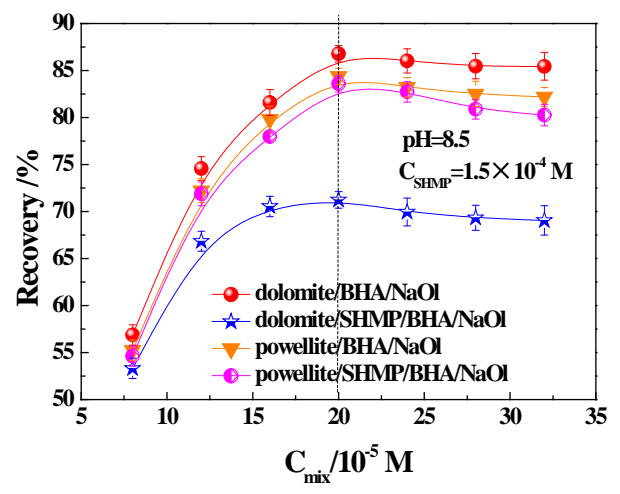

(b)

Figure 4. (a) Effect of the molar ratio of $\mathrm{NaOl} / \mathrm{BHA}$ on mineral recovery, and (b) the recovery response of minerals to the collector mixture concentration.

Figure 5a presents the investigation results of the flotation behavior of minerals with collector mixture at various SHMP concentrations. The SHMP concentration has no obvious influence on the flotation of powellite, while dolomite recovery decreases sharply to approximately $15 \%$ at a SHMP concentration of $25 \times 10^{-5} \mathrm{M}$. Then, a new reagent regime with using $25 \times 10^{-5} \mathrm{M} \mathrm{SHMP}$ as depressant and $20 \times 10^{-5} \mathrm{M}(\mathrm{NaOl})_{3}(\mathrm{BHA})$ as collector was determined. The flotation performance of the new reagent regime in the powellite/dolomite system at various $\mathrm{pH}$ values was studied (See Figure 5b). Powellite floats better than dolomite, and the selectivity of the new reagent regime for the minerals system is greater at $\mathrm{pH}$ ranges of $8-12$. The good adaptability of the reagent regime in a broader $\mathrm{pH}$ range favors control of the process in practical applications [32-34].

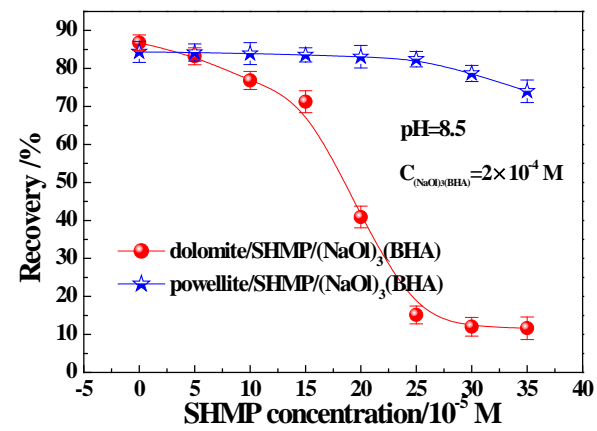

(a)

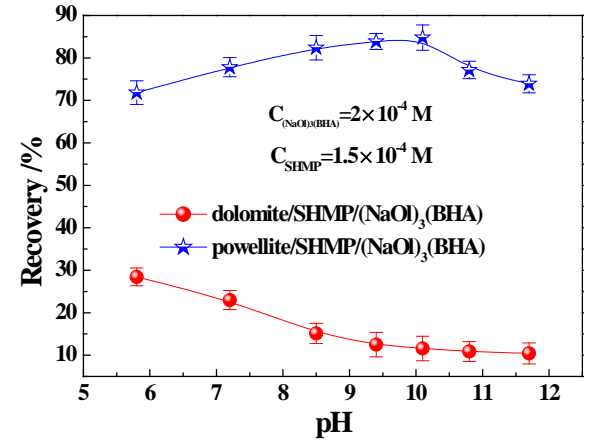

(b)

Figure 5. (a) Effect of SHMP concentration on mineral recovery using a collector mixture and (b) pulp $\mathrm{pH}$ on mineral recovery using the depressant SHMP with a collector mixture.

\subsection{Zeta Potential Measurements}

The adsorption behavior of charged reagents onto the mineral/water interface can be reflected by the change in the interface zeta potentials. The parameters were measured under different reagent conditions to reveal the mechanism of powellite/dolomite separation using the obtained new reagent regime, and the results are presented in Figure 6.

The isoelectric point (IEP) of raw dolomite is 5.6 as shown in Figure 6a, which is consistent with values reported in other papers [8,35]. At all of the tested $\mathrm{pH}$ values, raw powellite is negatively charged, and its IEP cannot be read in Figure $6 \mathrm{~b}$. The difference in the zeta potential of the powellite 
surface $(\sim 19 \mathrm{mV})$ after treatment with BHA is greater than that of the dolomite surface $(\sim 7 \mathrm{mV})$, revealing that $\mathrm{BHA}$ anions are more easily adsorbed on powellite. When the $\mathrm{pH}$ values were greater than 7.5, a greater decrease in zeta potential was noted for the raw dolomite surface than powellite after treatment with SHMP, revealing the stronger adsorption of the negatively charged depressant SHMP group on raw dolomite than raw powellite [36]. For the minerals treated with SHMP, BHA was added to detect the effect of the depressant on the adsorption of BHA. As shown in Figure 6a,b, the zeta potential of dolomite/SHMP exhibits reduced alterations than powellite/SHMP when BHA was introduced, showing that BHA is strongly adsorbed on the powellite surface. Thus, the preadsorbed SHMP has minimal effect on the BHA adsorption onto the powellite surface. On the other hand, the zeta potential reveals a 19-mV change from raw powellite to powellite/BHA and a similar 20-mV change from the powellite/SHMP to powellite/SHMP/BHA system at $\mathrm{pH} 8.5$, which also indicates the negligible impact of SHMP on the adsorption of BHA on powellite. In the dolomite/SHMP/BHA system, the introduction of $\mathrm{NaOl}$ causes an $8-\mathrm{mV}$ decrease, which is considerably less than the 22-mV variation from raw dolomite to dolomite/ $\mathrm{NaOl}$. This finding manifests the reductive effects of SHMP on the adsorption of $\mathrm{NaOl}$ onto dolomite. However, the $7-\mathrm{mV}$ difference in the zeta potential of powellite/SHMP/BHA to powellite/SHMP/BHA/NaOl is similar to the $6-\mathrm{mV}$ change from powellite to the powellite/ $\mathrm{NaOl}$ system, suggesting that $\mathrm{NaOl}$ adsorption on powellite is also not affected by the addition of SHMP [14,37].

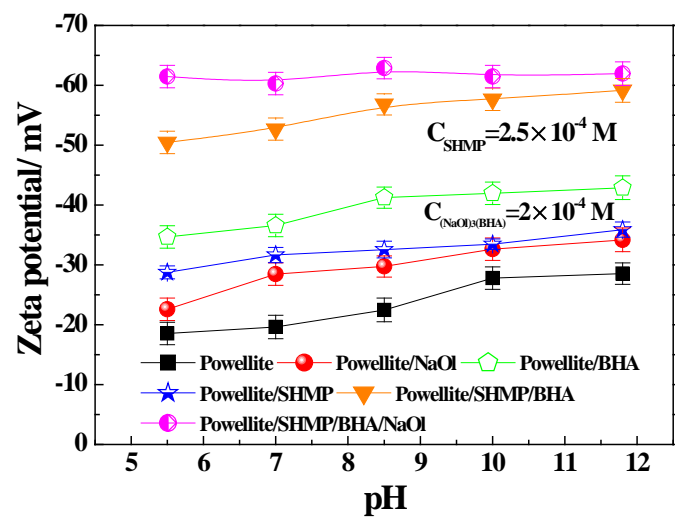

(a)

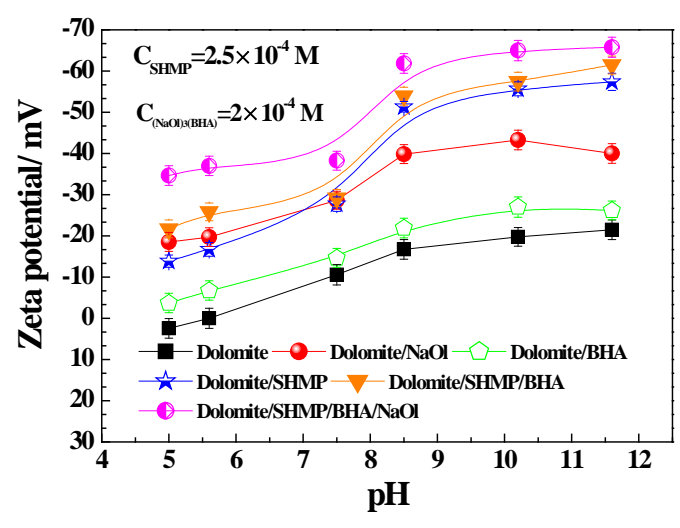

(b)

Figure 6. Zeta potential of dolomite (a) and powellite (b) before and after interaction with different reagents as a function of $\mathrm{pH}$.

\subsection{XPS Measurements}

The reagent/mineral interaction and the reason for the selective adsorption of SHMP and BHA was further explored using XPS detection and analysis. The results involving the atomic concentration and binding energy on the mineral surface with and without different reagents are displayed in Table 2. The concentrations of the major atoms on the minerals' surfaces show a shift after the addition of SHMP, $\mathrm{BHA}$, or $\mathrm{NaOl}$. After the addition of SHMP, the variation in the atom concentration of $\mathrm{P}$ on the surface of dolomite $(2.68 \%)$ is much greater than that on powellite $(0.19 \%)$, indicating a stronger adsorption of SHMP on the dolomite surface. On the other hand, the change in the $\mathrm{N}$ atom concentration on the powellite surface is also greater than the dolomite surface after treatment with BHA, which illustrates the selective adsorption of BHA on the two minerals [38]. The above results are consistent with the stronger depression of SHMP on dolomite than powellite and the greater recovery of powellite than dolomite in the BHA system as determined by microflotation tests.

Although $\mathrm{NaOl}$ also results in changes in the concentrations of the main atoms, it is difficult to obtain useful information. Thus, the binding energy shift of the principal atoms on the minerals' surface is discussed here. The nonselective adsorption of $\mathrm{NaOl}$ molecules on the surfaces of powellite and dolomite are indicated by the negligible difference in the chemical shift of $\mathrm{C}, \mathrm{O}, \mathrm{Ca}$, or $\mathrm{Mg}$ atoms 
on the surfaces of powellite and dolomite. When the data for $\mathrm{NaOl}$ and $\mathrm{BHA}$ adsorption on the same mineral were compared, the chemical shifts of the main atoms for $\mathrm{NaOl}$ adsorption are all greater than that for BHA adsorption, showing a stronger collecting power of $\mathrm{NaOl}$. Moreover, the $\mathrm{Ca}$ atom chemical shifts of dolomite $(0.37 \mathrm{eV})$ and powellite $(0.48 \mathrm{eV})$ are obviously attributed to treatment with BHA, but the variation in atom concentrations together with a difference of $0.11 \mathrm{eV}$ is sufficient to prove the selective adsorption performance. The greater difference in chemical shifts of $\mathrm{C}, \mathrm{O}, \mathrm{Ca}$, or $\mathrm{Mg}$ atoms on powellite $(\sim 0.1 \mathrm{eV})$ and dolomite $(\sim 0.5 \mathrm{eV})$ surfaces after the addition of SHMP offers evidence that SHMP adsorbs strongly on dolomite and weakly on powellite [39-41]. The XPS spectra of dolomite and powellite surface before and after interaction with reagents, and the XPS fine scanning spectra of $\mathrm{Ca}$ and $\mathrm{Mg}$ on dolomite and $\mathrm{Ca}$ on powellite are presented in Figure 7. After interaction with SHMP and BHA, the peaks of P2p and N1s occurred at around $132.8 \mathrm{eV}$ and $398.6 \mathrm{eV}$, respectively, suggesting the adsorption of the reagents onto minerals' surfaces. the XPS fine scanning spectra also show similar chemical shifts as that in Table 2.

Table 2. Binding energy and percentage of component elements on the mineral surface.

\begin{tabular}{|c|c|c|c|c|c|c|c|c|}
\hline Index & Minerals & Mo & $\mathrm{Ca}$ & Mg & $\mathrm{C}$ & $\mathbf{O}$ & $\mathbf{P}$ & $\mathbf{N}$ \\
\hline \multirow{8}{*}{ Percentage (at. \%) } & Dolomite & - & 8.42 & 6.79 & 39.30 & 45.49 & - & - \\
\hline & Dolomite/SHMP & - & 7.07 & 5.94 & 40.87 & 43.44 & 2.68 & - \\
\hline & Dolomite/BHA & - & 7.04 & 5.90 & 41.96 & 44.28 & - & 0.82 \\
\hline & Dolomite/NaOl & - & 6.97 & 5.85 & 42.24 & 44.94 & - & - \\
\hline & Powellite & 11.38 & 12.46 & - & 20.23 & 55.93 & - & - \\
\hline & Powellite/SHMP & 11.14 & 11.73 & & 23.46 & 53.48 & 0.19 & - \\
\hline & Powellite/BHA & 10.37 & 10.15 & - & 33.37 & 43.88 & - & 2.23 \\
\hline & Powellite/NaOl & 9.85 & 10.24 & & 34.67 & 45.24 & - & - \\
\hline \multirow{8}{*}{$\begin{array}{l}\text { Binding Energy } \\
(\mathrm{eV})\end{array}$} & Dolomite & - & 347.05 & 1303.88 & 285.36 & 531.52 & - & - \\
\hline & Dolomite/SHMP & - & $\begin{array}{l}346.60 \\
(-0.45)\end{array}$ & $\begin{array}{l}1303.45 \\
(-0.43)\end{array}$ & $\begin{array}{l}284.89 \\
(-0.47)\end{array}$ & $\begin{array}{l}532.38 \\
(0.86)\end{array}$ & 130.64 & - \\
\hline & Dolomite/BHA & - & $\begin{array}{l}346.68 \\
(-0.37)\end{array}$ & $\begin{array}{l}1303.52 \\
(-0.36)\end{array}$ & $\begin{array}{l}285.00 \\
(-0.36)\end{array}$ & $\begin{array}{l}532.26 \\
(0.74)\end{array}$ & - & 399.46 \\
\hline & Dolomite/NaOl & - & $\begin{array}{l}346.47 \\
(-0.58)\end{array}$ & $\begin{array}{l}1302.96 \\
(-0.56)\end{array}$ & $\begin{array}{l}284.78 \\
(-0.58)\end{array}$ & $\begin{array}{c}532.45 \\
(0.93)\end{array}$ & - & - \\
\hline & Powellite & 228.37 & 348.26 & - & 284.92 & 532.05 & - & - \\
\hline & Powellite/SHMP & $\begin{array}{l}228.35 \\
(-0.02)\end{array}$ & $\begin{array}{l}348.12 \\
(-0.14)\end{array}$ & - & $\begin{array}{l}284.80 \\
(-0.12)\end{array}$ & $\begin{array}{l}532.13 \\
(0.08)\end{array}$ & 130.72 & - \\
\hline & Powellite/BHA & $\begin{array}{l}228.34 \\
(-0.03)\end{array}$ & $\begin{array}{l}347.78 \\
(-0.48)\end{array}$ & - & $\begin{array}{l}284.41 \\
(-0.51)\end{array}$ & $\begin{array}{l}532.93 \\
(0.88)\end{array}$ & - & 399.49 \\
\hline & Powellite/NaOl & $\begin{array}{l}228.35 \\
(-0.02)\end{array}$ & $\begin{array}{l}347.74 \\
(-0.52)\end{array}$ & - & $\begin{array}{l}284.39 \\
(-0.53)\end{array}$ & $\begin{array}{c}532.92 \\
(0.87)\end{array}$ & - & - \\
\hline
\end{tabular}



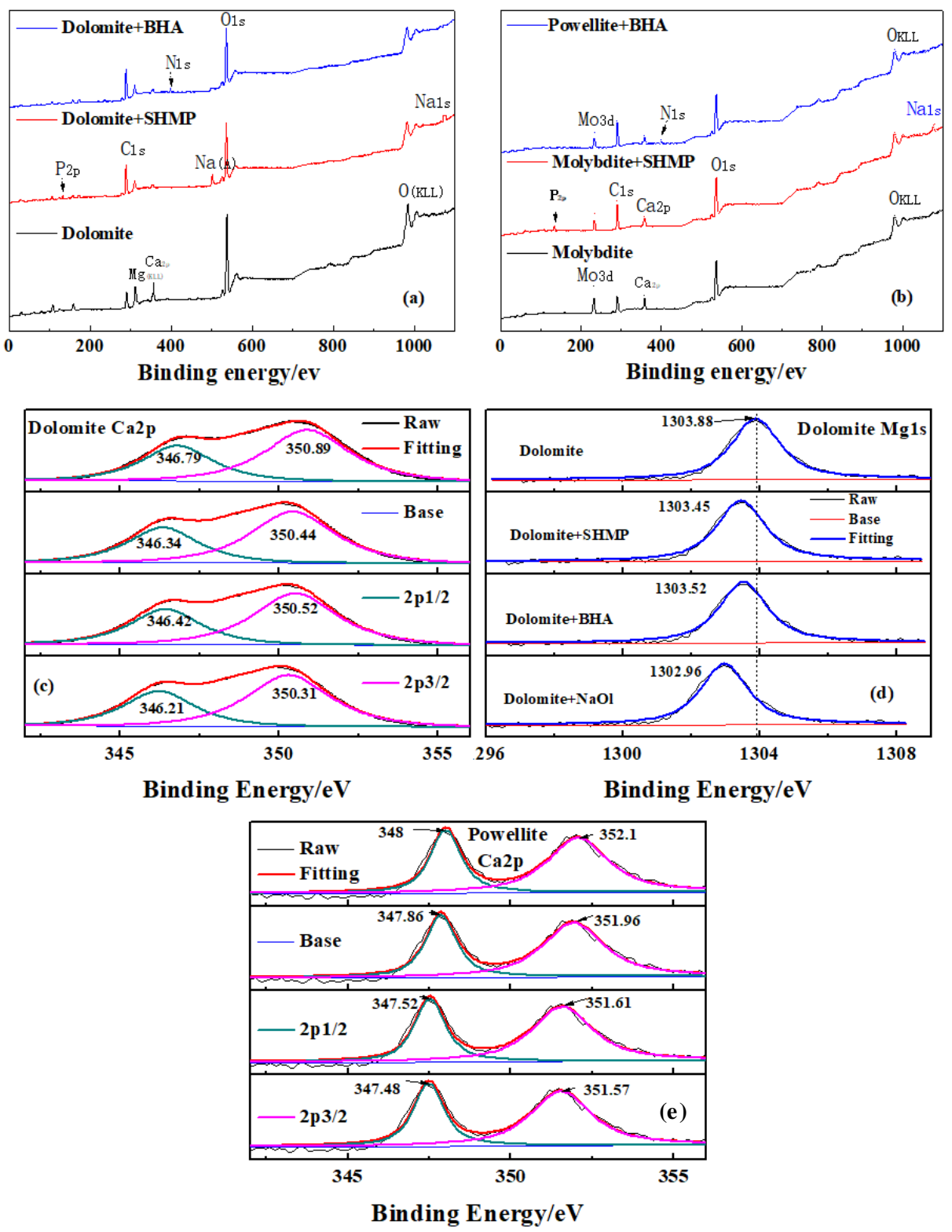

Figure 7. (a) XPS spectra of dolomite surface and (b) powellite surface; (c) XPS fine scanning spectra of (c) Ca and (d) Mg on dolomite; and (e) XPS fine scanning spectra of Ca on powellite.

\subsection{Crystal Chemistry and Interaction Energy Analysis}

The crystal chemistry of the mineral surface has a great influence on the adsorption of reagents according to previous papers $[14,40]$. To interpret selective SHMP adsorption on the surface of dolomite versus powellite, the $\mathrm{Ca}(\mathrm{Mg})-\mathrm{O}$ bond length and $\mathrm{Ca}+\mathrm{Mg}$ atom density on the minerals' surfaces was assessed and is shown in Figure 8 and Table 3. Table 3 reveals that the $\mathrm{Ca}(\mathrm{Mg})-\mathrm{O}$ bond length is 2.381 (2.087) and $2.465 \AA$ for dolomite and powellite, respectively, indicating that $\mathrm{Ca}(\mathrm{Mg})$ and $\mathrm{O}$ atoms on the dolomite surface are more tightly bonded. Under various external forces, the mineral tends to be broken and expose its cleavage. Breaking the more tightly bonded atoms requires more energy, resulting in more free energy and reactivity for the atoms that remain on the mineral surface. $\mathrm{Ca}(\mathrm{Mg})$ atoms on the cleavage (104) of dolomite own a higher bond energy and therefore show a higher reactivity for SHMP than those on powellite. The adsorption, wettability, dissolution, and floatability of minerals are mainly affected by the characteristics of the cleavage of the mineral, especially the density of active atom(s) on the surface. $\mathrm{Ca}+\mathrm{Mg}$ atom densities for the powellite (112) and dolomite (104) surfaces are 8.22 and $6.58 \mu \mathrm{mol} / \mathrm{m}^{2}$, respectively, and shown in Table 3. A higher $\mathrm{Ca}(\mathrm{Mg})$ atom 
density on the dolomite surface can allow the adsorption of more SHMP, leading to a greater shift towards the negative side of the potential of dolomite than that of powellite.

According to the zeta potential measurement and XPS detection results, the adsorption of $\mathrm{NaOl}$ on powellite and dolomite surfaces is less selective compared with BHA. Here, the $\mathrm{O}-\mathrm{O}$ distance was employed to offer an explanation to some extent. The $\mathrm{O}-\mathrm{O}$ distance for minerals and collectors is also presented in Table 3. The values for $\mathrm{CO}_{3}^{2-}$ in dolomite, $\mathrm{MoO}_{4}^{2-}$ in powellite, $-\mathrm{COOH}$ in $\mathrm{NaOl}$, and $-(\mathrm{C}=\mathrm{O})-\mathrm{N}-\mathrm{OH}$ in $\mathrm{BHA}$ are 2.222, 2.848, 2.615, and $3.006 \AA$, respectively. According to reports in some literature, a saline mineral and reagent with similar $\mathrm{O}-\mathrm{O}$ distances are readily able to interact with each other $[42,43]$. The $\mathrm{O}-\mathrm{O}$ distance of $\mathrm{NaOl}$ falls in between that of dolomite and powellite, so $\mathrm{NaOl}$ presented a poor selectivity in flotation tests. The $\mathrm{O}-\mathrm{O}$ distance of $\mathrm{BHA}$ is relatively close to that of powellite and mismatched with that of dolomite, leading to the selective flotation of BHA on powellite to some extent.

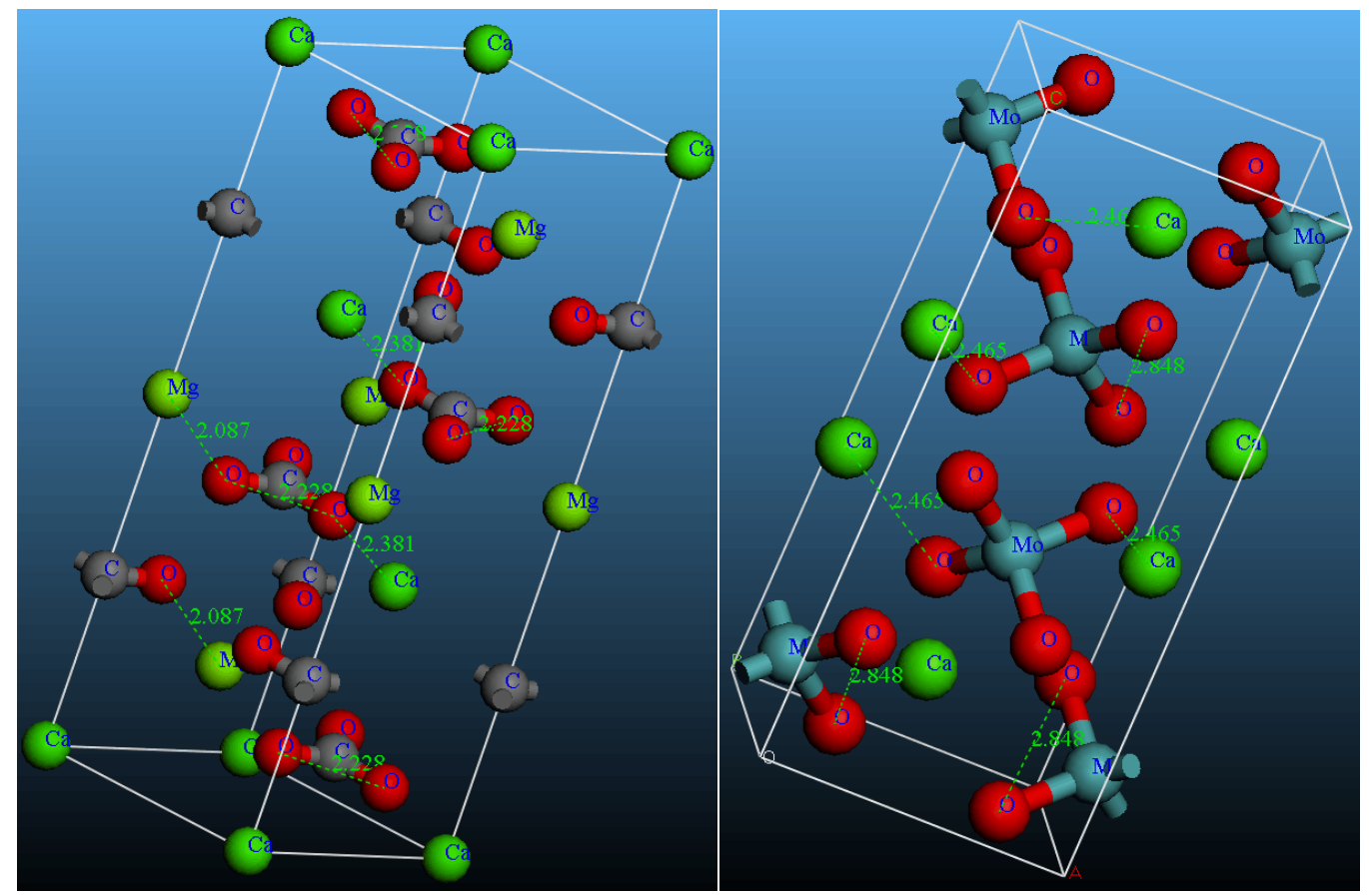

Figure 8. The optimized unit cell of dolomite and powellite with labeled $\mathrm{O}-\mathrm{O}$ distance and $\mathrm{Ca}-\mathrm{O}$ bond length (gray, C; red, O; blue, N; green, Ca; green-yellow, Mg; and cyan, Mo).

Table 3. Crystal and structure chemical parameters of minerals and reagents.

\begin{tabular}{cccc}
\hline \multirow{2}{*}{ Mineral } & \multicolumn{3}{c}{ Characteristic Parameters } \\
\cline { 2 - 4 } & $\mathbf{O}-\mathbf{O} / \mathbf{A}$ & $\mathbf{C a}(\mathbf{M g})-\mathbf{O} / \AA$ & $\mathbf{D}_{(\mathbf{C a}+\mathbf{M g})} /\left(\mu \mathbf{m o l} \cdot \mathbf{m}^{-\mathbf{2}}\right)$ \\
\hline Dolomite & 2.222 & $2.381(2.087)$ & 8.22 \\
Powellite & 2.848 & 2.465 & 6.58 \\
NaOl & 2.615 & - & - \\
BHA & 3.006 & - & - \\
\hline
\end{tabular}

The adsorption energies of $\mathrm{NaOl}, \mathrm{BHA}, \mathrm{SHMP}$, and $\mathrm{NaOl} / \mathrm{BHA}$ on two minerals were calculated using Material Studio 5.0 package, and the results are presented in Table 4. Adsorption energies of -216.87 and $-203.52 \mathrm{~kJ} / \mathrm{mol}$ for $\mathrm{NaOl} / \mathrm{calcite}$ and $\mathrm{NaOl} /$ powellite systems, respectively, are very similar and are consistent with the inferior selectivity of $\mathrm{NaOl}$ adsorption on the two minerals. Regarding $\mathrm{BHA}$ or SHMP, the greater difference in the adsorption energies of the reagent/powellite and reagent/dolomite systems is a good indicator for their selective adsorption and flotation on dolomite and powellite. Using the combination of $\mathrm{NaOl} / \mathrm{BHA}$ as a collector, the adsorption energies are all increased compared 
with a single collector, but the increment between $\mathrm{NaOl} / \mathrm{BHA}$ and $\mathrm{NaOl}$ collectors on powellite is much greater than that of dolomite, which illustrates that the combination of BHA with $\mathrm{NaOl}$ improves collecting power of $\mathrm{NaOl}$ and the selectivity of BHA. The calculation results are consistent with XPS, zeta, and flotation results.

Table 4. Adsorption energies of minerals with reagents.

\begin{tabular}{ccccc}
\hline \multirow{2}{*}{ Mineral } & \multicolumn{4}{c}{ Adsorption Energy $(\triangle E, \mathbf{k J} / \mathbf{m o l})$} \\
\cline { 2 - 5 } & NaOl & BHA & SHMP & NaOl/BHA \\
\hline Dolomite & -216.87 & -98.15 & -196.53 & -235.76 \\
Powellite & -203.52 & -174.64 & -47.16 & -387.28 \\
\hline
\end{tabular}

\subsection{Proposed Mechanism}

Figure 9 shows an adsorption model based on the results reported above, which summarizes the separation mechanism of the flotation of powellite from dolomite using the new reagent regime. The greater $\mathrm{Ca}+\mathrm{Mg}$ density and activity of dolomite make the adsorption of SHMP on the surface easier compared with that of powellite. The selective adsorption of SHMP results in a greater negative shift of dolomite's zeta potential from 'mineral' to 'mineral/SHMP'. NaOl adsorption on the powellite surface is minimally affected by preadsorbed SHMP but is inhibited on the dolomite surface due to the increased adsorption of depressant molecules. In Figure 9, the reduced levels of BHA on dolomite compared with powellite could be attributed to two reasons: the selective adsorption of BHA on powellite due to the better matching $\mathrm{O}-\mathrm{O}$ distance of $\mathrm{BHA}$ with that of $\mathrm{MoO}_{4}^{2-}$ in powellite and the selective depression of SHMP on the adsorption of BHA on dolomite. Given the increased collector adsorption density on powellite, the hydrophobic interaction of the hydrocarbon chain between the same and the different collector molecules strengthens the hydrophobicity of the mineral surface. The adsorption of the negatively charged collectors onto negatively charged mineral surfaces and depressant together with the XPS detection results demonstrate the chemisorption of any single unit of the new reagent regime on the surfaces of the two minerals.

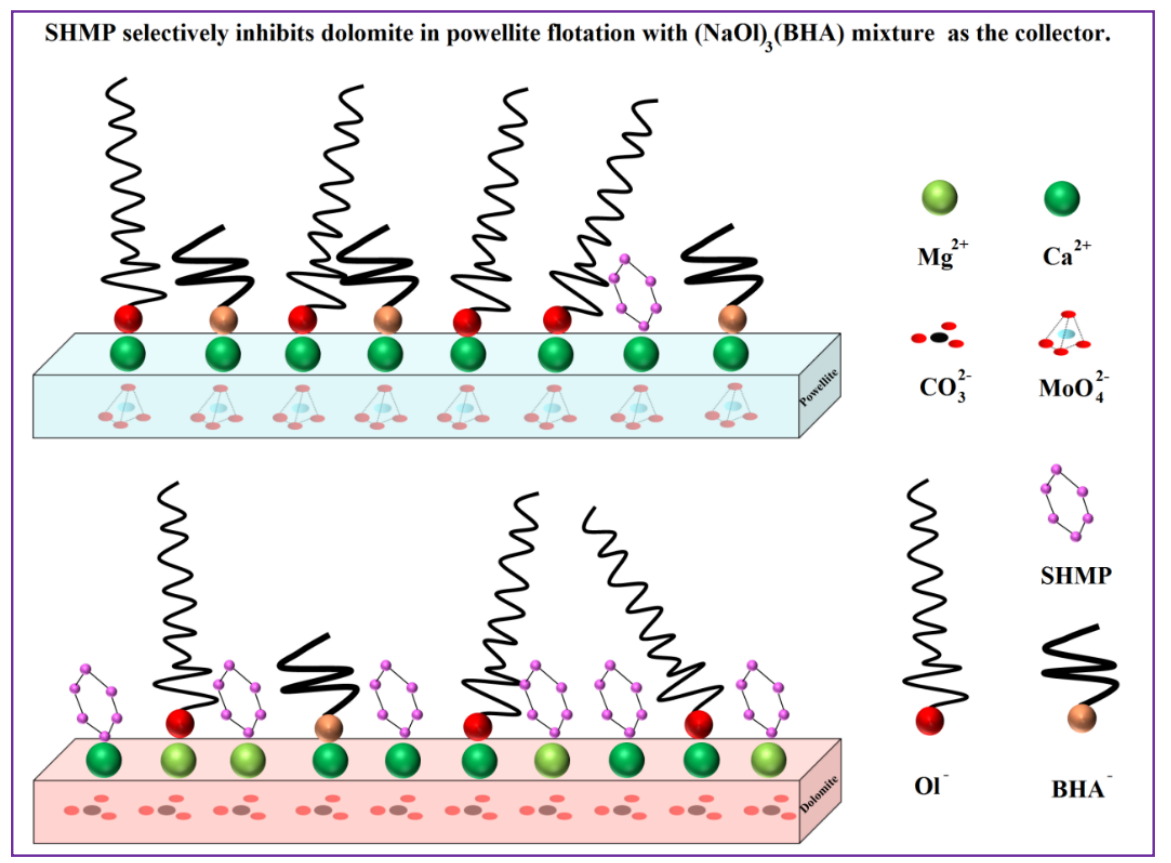

Figure 9. Schematic diagram of the selective depression mechanism of SHMP for the flotation of powellite from dolomite with mixed NaOl/BHA collector (condition: $25 \times 10^{-5} \mathrm{M} \mathrm{SHMP} ; 15 \times 10^{-5} \mathrm{M}$ $\mathrm{NaOl}$; and $5 \times 10^{-5} \mathrm{M} \mathrm{BHA}$; $\mathrm{pH}$ 9-10). 


\section{Conclusions}

The introduction of $\mathrm{BHA}$ into $\mathrm{NaOl}$ at a 1:3 molar ratio increases the adsorption ability and flotation selectivity of $\mathrm{NaOl}$ on powellite and dolomite. Using the combination of the collector mixture $(\mathrm{NaOl})_{3}(\mathrm{BHA})$ and the depressant SHMP, a new reagent regime $\left(2.5 \times 10^{-4} \mathrm{M} \mathrm{SHMP}, 2 \times 10^{-4} \mathrm{M}\right.$ mixed collector) was established, and the $\mathrm{pH}$ range for highly efficient separation of powellite and dolomite is $8-12$. The adsorption of $\mathrm{NaOl}$ on the two minerals is strong and nonselective. While that of BHA reflects selectivity: it was more easily adsorbed onto powellite surface than dolomite surface, which can be ascribed to the better matching $\mathrm{O}-\mathrm{O}$ distance of $\mathrm{BHA}$ with that of $\mathrm{MoO}_{4}^{2-}$ in powellite against $\mathrm{CO}_{3}^{2-}$ in dolomite. Preadsorbed SHMP selectively inhibits $\mathrm{NaOl}$ and $\mathrm{BHA}$ adsorption onto dolomite but has minimal effects on the adsorption of the two collectors onto powellite. The structural chemical properties of the collector molecule and the crystal chemical properties of minerals affect their adsorption and thus the flotation behavior.

Author Contributions: Conceptualization, Z.W. and Y.Q.; methodology, W.D.; software, Y.P.; validation, Z.W.; investigation, Y.Q.; resources, Z.W.; data curation, Y.Q.; writing-original draft preparation, Y.Q.; writing一review and editing, Z.W.; visualization, W.D.; funding acquisition, Z.W. All authors have read and agreed to the published version of the manuscript.

Funding: This research was funded by the Basic Scientific Research Program of Wenzhou, grant number G20180031, the General Research of Education of Zhejiang Province, grant number Y201839560, the Key Scientific Research Program of Zhejiang college of Security Technology, grant number AF2018Z01 and the Sichuan Science and Technology Program of China, grant number 2018 SZ0282.

Conflicts of Interest: The authors declare no conflict of interest.

\section{References}

1. Wang, Z.; Wang, L.; Zheng, Y.; Xiao, J. Role of calcium dioleate in the flotation of powellite particles using oleate. Miner. Eng. 2019, 138, 95-100. [CrossRef]

2. Espiritu, E.R.L.; Naseri, S.; Waters, K.E. Surface chemistry and flotation behavior of dolomite, monazite and bastnäsite in the presence of benzohydroxamate, sodium oleate and phosphoric acid ester collectors. Colloids Surf. A 2018, 546, 254-265. [CrossRef]

3. Zhang, H.; Han, C.; Liu, W.; Hou, D.; Wei, D. The chain length and isomeric effects of monohydric alcohols on the flotation of magnesite and dolomite by sodium oleate. J. Mol. Liq. 2019, 276, 471-479. [CrossRef]

4. Yang, F.; Sun, W.; Hu, Y.; Long, S. Cationic flotation of scheelite from calcite using quaternary ammonium salts as collector: Adsorption behavior and mechanism. Miner. Eng. 2015, 81, 18-28. [CrossRef]

5. Han, H.; Hu, Y.; Sun, W.; Li, X.; Cao, C.; Yue, T.; Meng, X.; Guo, Y.; Wang, J.; Gao, Z.; et al. Fatty acid flotation versus BHA flotation of tungsten minerals and their performance in flotation practice. Int. J. Miner. Process. 2017, 159, 22-29. [CrossRef]

6. Kupka, N.; Rudolph, M. Froth flotation of scheelite-A review. Int. J. Miner. Sci. Technol. 2018, $28,373-384$. [CrossRef]

7. Zhang, W.; Honaker, R.Q.; Groppo, J.G. Flotation of monazite in the presence of calcite part I: Calcium ion effects on the adsorption of hydroxamic acid. Miner. Eng. 2017, 100, 40-48. [CrossRef]

8. Espiritu, E.R.L.; Waters, K.E. Flotation studies of monazite and dolomite. Miner. Eng. 2018, 116, $101-106$. [CrossRef]

9. Tian, M.; Gao, Z.; Ji, B.; Fan, R.; Liu, R.; Chen, P.; Sun, W.; Hu, Y. Selective flotation of cassiterite from calcite with salicylhydroxamic acid collector and carboxymethyl cellulose depressant. Minerals 2018, 8, 316. [CrossRef]

10. Deng, L.; Zhao, G.; Zhong, H.; Wang, S.; Liu, G. Investigation on the selectivity of N-((hydroxyamino)-alkyl) alkylamide surfactants for scheelite/calcite flotation separation. J. Ind. Eng. Chem. 2016, 33, 131-141. [CrossRef]

11. Rai, B.; Rao, T.K.; Krishnamurthy, S.; Vetrivel, R.; Mielczarski, J.; Cases, J.M. Molecular modeling of interactions of alkyl hydroxamates with calcium minerals. J. Colloid Interf. Sci. 2002, 256, 106-113.

12. Yan, W.; Liu, C.; Ai, G.; Feng, Q.; Zhang, W. Flotation separation of scheelite from calcite using mixed collectors. Int. J. Miner. Process. 2017, 169, 106-110. [CrossRef] 
13. Jiang, W.; Gao, Z.; Khoso, S.A.; Gao, J.; Sun, W.; Pu, W.; Hu, Y. Selective adsorption of benzhydroxamic acid on fluorite rendering selective separation of fluorite/calcite. Appl. Surf. Sci. 2018, 435, 752-758. [CrossRef]

14. Gao, Y.; Gao, Z.; Sun, W.; Hu, Y. Selective flotation of scheelite from calcite: A novel reagent scheme. Int. J. Miner. Process. 2016, 154, 10-15. [CrossRef]

15. Azizi, D.; Larachi, F. Surface interactions and flotation behavior of calcite, dolomite and ankerite with alkyl hydroxamic acid bearing collector and sodium silicate. Colloids Surf. A 2018, 537, 126-138. [CrossRef]

16. Wang, Z. The adsorption of oleate on powellite and fluorapatite: A joint experimental and theoretical simulation study. Appl. Surf. Sci. 2017, 409, 65-70.

17. Wang, Z.; Xu, L.; Wang, J.; Wang, L.; Xiao, J. A comparison study of adsorption of benzohydroxamic acid and amyl xanthate on smithsonite with dodecylamine as co-collector. Appl. Surf. Sci. 2017, 426, 1141-1147. [CrossRef]

18. Lyu, F.; Gao, J.; Sun, N.; Liu, R.; Sun, X.; Cao, X.; Wang, L.; Sun, W. Utilisation of propyl gallate as a novel selective collector for diaspore flotation. Miner. Eng. 2019, 131, 66-72. [CrossRef]

19. Liu, J.; Wang, Y.; Luo, D.; Zeng, Y. Use of ZnSO4 and SDD mixture as sphalerite depressant in copper flotation. Miner. Eng. 2018, 121, 31-38. [CrossRef]

20. Manono, M.; Corin, K.; Wiese, J. The effect of the ionic strength of process water on the interaction of talc and CMC: Implications of recirculated water on floatable gangue depression. Minerals 2019, 9, 231. [CrossRef]

21. Manono, M.; Corin, K.; Wiese, J. Inorganic electrolytes on the efficacy of a carboxymethyl cellulose as a coagulant for talc: Implications for talc depression in flotation. In Proceedings of the International Mine Water Association Congress, Perm, Russia, 15-19 July 2019.

22. Tian, M.; Liu, R.; Gao, Z.; Chen, P.; Han, H.; Wang, L.; Zhang, C.; Sun, W.; Sun, Y. Activation mechanism of Fe (III) ions in cassiterite flotation with benzohydroxamic acid collector. Miner. Eng. 2018, 119, 31-37. [CrossRef]

23. Wang, L.; Hu, G.; Sun, W.; Khoso, S.A.; Liu, R.; Zhang, X. Selective flotation of smithsonite from dolomite by using novel mixed collector system. Trans. Nonferr. Met. Soc. China 2019, 29, 1082-1089. [CrossRef]

24. Abdalla, M.A.M.; Peng, H.; Younus, H.A.; Wu, D.; Abusin, L.; Shao, H. Effect of synthesized mustard soap on the scheelite surface during flotation. Colloid Surf. A 2018, 548, 108-116. [CrossRef]

25. Mabudi, A.; Noaparast, M.; Gharabaghi, M.; Vasquez, V.R. Polystyrene nanoparticles as a flotation collector: A molecular dynamics study. J. Mol. Liq. 2019, 275, 554-566. [CrossRef]

26. Wang, L.; Liu, R.; Hu, Y.; Sun, W. Adsorption of mixed DDA/NaOL surfactants at the air/water interface by molecular dynamics simulations. Chem. Eng. Sci. 2016, 155, 167-174. [CrossRef]

27. Wang, L.; Sun, N.; Wang, Z.; Han, H.; Yang, Y.; Liu, R.; Hu, Y.; Tang, H.; Sun, W. Self-assembly of mixed dodecylamine-dodecanol molecules at the air/water interface based on large-scale molecular dynamics. J. Mol. Liq. 2019, 276, 867-874. [CrossRef]

28. Wang, Z.; Xu, L.; Liu, R.; Sun, W.; Xiao, J. Comparative studies of flotation and adsorption with cetyl pyridinium chloride on molybdite and fluorapatite. Int. J. Miner. Process. 2015, 143, 112-116. [CrossRef]

29. Gallios, G.P.; Matis, K.A. Floatability of magnesium carbonates by sodium oleate in the presence of modifiers. Sep. Sci. Technol. 1989, 24, 129-143. [CrossRef]

30. Matis, K.A.; Gallios, G.P. Anionic flotation of magnesium carbonates by modifiers. Int. J. Miner. Process. 1989, 25, 261-274. [CrossRef]

31. Abarca, C.; Ali, M.M.; Pelton, R.H. Choosing mineral flotation collectors from large nanoparticle libraries. J. Colloid Interf. Sci. 2018, 516, 423-430. [CrossRef]

32. Roy, S.; Datta, A.; Rehani, S. Flotation of copper sulphide from copper smelter slag using multiple collectors and their mixtures. Int. J. Miner. Process. 2015, 143, 43-49. [CrossRef]

33. Taguta, J.; O'Connor, C.T.; McFadzean, B. Investigating the interaction of thiol collectors and collector mixtures with sulphide minerals using thermochemistry and microflotation. Miner. Eng. 2018, 119, 99-104. [CrossRef]

34. Li, Z.; Fu, Y.; Li, Z.; Nan, N.; Zhu, Y.; Li, Y. Froth flotation giant surfactants. Polymer 2019, 162, 58-62. [CrossRef]

35. Peleka, E.N.; Gallios, G.P.; Matis, K.A. A perspective on flotation: A review. J. Chem. Technol. Biotechnol. 2018, 93, 615-623. [CrossRef]

36. Meng, Q.; Yuan, Z.; Yu, L.; Xu, Y.; Du, Y.; Zhang, C. Selective depression of titanaugite in the ilmenite flotation with carboxymethyl starch. Appl. Surf. Sci. 2018, 440, 955-962. [CrossRef] 
37. Araújo, A.C.A.; Lima, R.M.F. Influence of cations $\mathrm{Ca}^{2+}, \mathrm{Mg}^{2+}$ and $\mathrm{Zn}^{2+}$ on the flotation and surface charge of smithsonite and dolomite with sodium oleate and sodium silicate. Int. J. Miner. Process. 2017, 167, $35-41$. [CrossRef]

38. Multani, R.S.; Williams, H.; Johnson, B.; Li, R.; Waters, K.E. The effect of superstructure on the zeta potential, xanthate adsorption, and flotation response of pyrrhotite. Colloids Surf. A 2018, 551, 108-116. [CrossRef]

39. Feng, B.; Luo, X.; Wang, J.; Wang, P. The flotation separation of scheelite from calcite using acidified sodium silicate as depressant. Miner. Eng. 2015, 80, 45-49.

40. Filippova, I.V.; Filippov, L.O.; Lafhaj, Z.; Barres, O.; Fornasiero, D. Effect of calcium minerals reactivity on fatty acids adsorption and flotation. Colloid Surf. A 2018, 545, 157-166. [CrossRef]

41. Zhang, N.; Ejtemaei, M.; Nguyen, A.V.; Zhou, C. XPS analysis of the surface chemistry of sulfuric acid-treated kaolinite and diaspore minerals with flotation reagents. Miner. Eng. 2019, 136, 1-7. [CrossRef]

42. Gao, Y.; Gao, Z.; Sun, W.; Yin, Z.; Wang, J.; Hu, Y. Adsorption of a novel reagent scheme on scheelite and calcite causing an effective flotation separation. J. Colloid Interf. Sci. 2018, 512, 39-46. [CrossRef] [PubMed]

43. Yin, W.; Wang, J. Effects of particle size and particle interactions on scheelite flotation. Trans. Nonferr. Met. Soc. China 2014, 24, 3682-3687. [CrossRef]

(C) 2020 by the authors. Licensee MDPI, Basel, Switzerland. This article is an open access article distributed under the terms and conditions of the Creative Commons Attribution (CC BY) license (http://creativecommons.org/licenses/by/4.0/). 